\title{
Obituaries
}

Obituaries should be submitted by email to Kate Maynard at k.maynard@nature.com.

All submitted obituaries should be 350 words maximum in length (apart from obituaries for past presidents of the BDA

where the length should be 700-800 words).

Content of the obituary is down to the individual author, and the approval of the family should be given for the obituary prior

to submission to the $B D J$.

\section{MICHAEL STEPHEN WOODWARD}

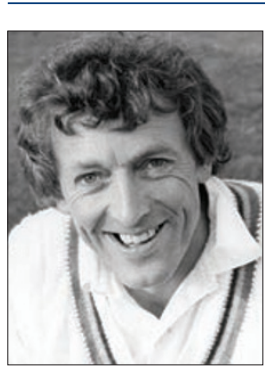

Mike Woodward passed away on 13 May 2010. Born on 25 November 1936 and an old boy of King Edward the Sixth Grammar School, Camp Hill, Birmingham, Mike graduated from Birmingham in 1961, along with his great friend, Neville Hall, who gave a tribute at Mike's service of Thanksgiving on 28 May.

On graduation Mike joined a local practice part-time in Hall Green, Birmingham, the other half of his working week being at the School Clinic Service in Stratford upon Avon. Philip Evans, the practice principal, liked Birmingham graduates and Mike gained invaluable experience from him, eventually setting up his own practice at 3, Highland Street, Ivybridge in 1972 where he worked happily for nearly 25 years until his retirement in October 1996.

In September 1961 Mike married Angela, and in 1964 moved to Plymouth, where he joined a dental practice on Mutley Plain to work with Owen Sims and David Endacott.

At that time he became involved with the British Dental Association and its local dental committees, serving as the Plymouth Section's treasurer until his retirement. It was with some amusement that the present treasurer found that, despite numerous attempts by the bank to change the details, Mike still remains on their computer as the section treasurer! For many years Mike and Angela were key to the success of the exchange visits between Plymouth and Brest dentists, making use of Angela's excellent language skills.

Mike was a dedicated family man, caring and generous, professionally very ethical. He was always willing to help others, which he would do in a quiet and ordered manner. Whatever he became involved with, he was always supportive in every way. We have all lost a loyal friend.

Mike was always a keen cricketer and in cricket terms, although Mike has been bowled out, the life-long innings that he has played have been magnificent in every way, and will not be forgotten.

Our thoughts are with Angela, Stephen and his family and Andy at their time of sadness.

BKA, NH and $\mathrm{AW}$

\section{DAYALI CHHAGANLAL KARIA}

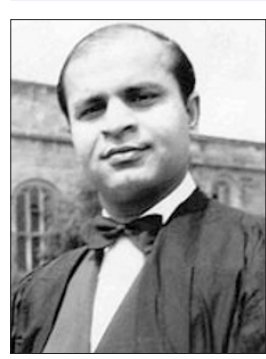

Dayalji Chhaganlal Karia was in born in Rajkot, India on 10 February 1928. In 1934, his father secured employment as a warden at a community hostel for boys in Kampala, Uganda, Africa. Dayalji followed at the age of 14 with his three sisters. There, he studied at the Government Secondary School and passed his Senior Cambridge examination.

In 1948, he was admitted to Durham University to study dentistry. Against all odds and through sponsorship from his community, he travelled to England. He managed to find accommodation on Hotspur Street, Newcastle with a landlady called Mrs Horne who looked after him as her own son (and who he remembered with fondness).
Dayalji qualified as a dentist in 1953 and returned to Kampala to set up a dental practice. In 1956, he travelled to India to marry his wife, Shashi. As his parents retired and returned to India, Dayalji decided to leave Africa and settle in London in 1965.

After working in various practices, he set up his own NHS practice in Kingsbury, North London in 1968. It was during this time that his two daughters were born. In 1976, he closed his practice in order to settle in India. However, due to the ill health of his family, he returned to London after two years.

Dayalji joined the Redbridge Dental Department as a children's dentist at Newbury Park Health Centre. In 1986 he was promoted to Senior Dental Officer. He had special responsibility for the elderly and long-stay sectors where he was based at Goodmayes Hospital. His rapport with children and most of all elderly patients was remarkable. He always remembered his nurse at that time, Jackie, as they made such a great team.

He retired in 1991 in order to spend more time with family and in his garden which he was particularly proud of.

He moved to North Finchley N12 in 1997. He was a loving husband of 53 years, a proud father and the ecstatic grandfather of four grandchildren. He was considerate, compassionate, philosophical, and witty. He had a wonderful hearty laugh.

He died unexpectedly on 27 July 2009.

Rupal/Parul 